Original Paper

\title{
Lipopolysaccharides (LPS) Induced Angiogenesis During Chicken Embryogenesis is Abolished by Combined ETA/ETB Receptor Blockade
}

\author{
Guang Wang a,d Pei-zhi Lia Shi-yao Zhanga Shan Zhonga Chang Chuce \\ Shufei Zeng ${ }^{c, e}$ Yu Yann ${ }^{a, d}$ Xin Cheng ${ }^{a, d}$ Manli Chuai ${ }^{b}$ Berthold Hocher, \\ Xuesong Yanga,d
}

International Joint Laboratory for Embryonic Development \& Prenatal Medicine, Division of Histology and Embryology, Medical College, Jinan University, Guangzhou, China, ${ }^{b}$ Division of Cell and Developmental Biology, University of Dundee, Dundee, UK, Institute of Nutritional Science, University of Potsdam, Potsdam-Nuthetal, Germany, ${ }^{~}$ Key Laboratory for Regenerative Medicine of the Ministry of Education, Jinan University, Guangzhou, eDepartments of Nephrology, the First Affiliated Hospital, Jinan University, Guangzhou, China

\section{Key Words}

Lipopolysaccharides (LPS) - Angiogenesis - Chicken chorioallantoic membrane (CAM) • Endothelin (ET)

\begin{abstract}
Background/Aims: Angiogenesis plays a key role during embryonic development. The vascular endothelin (ET) system is involved in the regulation of angiogenesis. Lipopolysaccharides (LPS) could induce angiogenesis. The effects of ET blockers on baseline and LPS-stimulated angiogenesis during embryonic development remain unknown so far. Methods: The blood vessel density (BVD) of chorioallantoic membranes (CAMs), which were treated with saline (control), LPS, and/or BQ123 and the ETB blocker BQ788, were quantified and analyzed using an IPP 6.0 image analysis program. Moreover, the expressions of ET-1, ET-2, ET3, ET receptor A (ETRA), ET receptor B (ETRB) and VEGFR2 mRNA during embryogenesis were analyzed by semi-quantitative RT-PCR. Results: All components of the ET system are detectable during chicken embryogenesis. LPS increased angiogenesis substantially. This process was completely blocked by the treatment of a combination of the ETA receptor blockers-BQ123 and the ETB receptor blocker BQ788. This effect was accompanied by a decrease in ETRA, ETRB, and VEGFR2 gene expression. However, the baseline angiogenesis was not affected by combined ETA/ETB receptor blockade. Conclusion: During chicken embryogenesis, the LPSstimulated angiogenesis, but not baseline angiogenesis, is sensitive to combined ETA/ETB receptor blockade.

Guang Wang and Pei-zhi Li contributed equally to this work.




\section{Introduction}

Endothelin-1 (ET-1) has been shown to play a key role in the pathogenesis of cardiac and renal diseases [1-5]. It is elevated in patients with essential hypertension [6] and in particular pregnant women with pregnancy induced hypertension [7]. Besides its role in renal and cardiovascular diseases, ET-1 might play a role in angiogenesis during embryonic development as well, since it is known that ET-1 might interact with factors critical for angiogenesis during embryonic development. In the current study, we analyzed the timedependent mRNA expression of components of the ET system in the whole chicken embryos, and in the chicken chorioallantoic membranes (CAMs), as well as the effects of blocking both ET receptors on LPS-stimulated angiogenesis in CAMs.

\section{Materials and Methods}

Assessment of angiogenesis using CAMs

Chicken eggs (obtained from the Avian Farm of the South China Agriculture University) were incubated for 5, 7, and 9 days respectively, to analyze the mRNA expression of ET1, ET2 and ET3 as well as ET receptors and VEGFR2. The 7-day CAMs were treated with LPS (10 or $100 \mu \mathrm{g} / \mathrm{ml})$. A combined ETA and ETB receptor blockade was achieved by simultaneously treating the eggs with BQ123 and BQ788 (1, 5 or 10 $\mu \mathrm{g} / \mathrm{ml}$ respectively) or saline (control) for 48 hours. All surviving embryos were harvested for analysis. The CAMs and accompanying blood vessels in the control, BQ123 and BQ788 or/and LPS-treated groups were photographed using a Canon Powershot SX130 IS digital camera (12.1M Pixels). The color pictures were turned to grayscale pictures by Photoshop.

\section{Semiquantitative RT-PCR}

Total RNA was isolated from the gastrula chicken embryos or chicken CAM tissues using a Trizol kit (Invitrogen, USA) according to the manufacturer's instructions. First-strand cDNA was synthesized to a final volume of $25 \mu \mathrm{l}$ using SuperScript RIII first-strand (Invitrogen, USA). Following reverse transcription, PCR amplification of the cDNA was performed. The sets of primers used for semi-quantitative RT-PCR are provided in the Table 1. The PCR reactions were performed in a Bio-Rad S1000TM Thermal cycler (Bio-Rad, USA). The final reaction volume was $50 \mu \mathrm{l}$ composed of $1 \mu \mathrm{l}$ of first-strand cDNA, $25 \mu \mathrm{M}$ forward primer, $25 \mu \mathrm{M}$ reverse primer, $10 \mu \mathrm{l}$ PrimeSTARTM Buffer (Mg2+ plus), $4 \mu \mathrm{l}$ dNTPs Mixture (TaKaRa, Japan), $0.5 \mu \mathrm{l}$ PrimeSTARTM HS DNA Polymerase (2.5 U/ $\mu \mathrm{l} \mathrm{TaKaRa,} \mathrm{Japan),} \mathrm{and} \mathrm{RNase-free} \mathrm{water.} \mathrm{cDNA} \mathrm{was} \mathrm{amplified} \mathrm{for}$ 30 cycles. One round of amplification was performed at $94^{\circ} \mathrm{C}$ for $30 \mathrm{~s}, 30 \mathrm{~s}$ at $58^{\circ} \mathrm{C}$, and $30 \mathrm{~s}$ at $72^{\circ} \mathrm{C}$. The PCR products $(20 \mu \mathrm{l})$ were resolved using $1 \%$ agarose gels (Biowest, Spain) in $1 \times$ TAE buffer $(0.04 \mathrm{M}$ Trisacetate and $0.001 \mathrm{M} \mathrm{EDTA}$ ) and 10, 000× GeneGreen Nucleic Acid Dye (TIANGEN, China) solution. The resolved products were visualized using a transilluminator (SYNGENE, UK), and photographed using a computerassisted gel documentation system (SYNGENE, UK). All experiments were replicated at least three times.

\section{Data analysis}

The blood vessel density (BVD) were quantified and analyzed as follows. The areas occupied by the blood vessel plexus were quantified using an IPP 6.0 image analysis program. The BVD was expressed as the percentage of area occupied by the blood vessel over the whole area under the microscopic field as previously described [8-11]. Statistical analysis
Table 1. Primers sets used in the RT-PCR analysis

\begin{tabular}{lcc}
\hline Primers & \multicolumn{1}{c}{ Forward } & Reverse \\
\hline ET-1 & GGAGCTGTTTACCCCACTC & GTGCCCTTTTAACGGGGAGA \\
ET-2 & GAGCTGTCCAAGTCAGACGC & TCAGCCCAAGTGCCCTTTTA \\
ET-3 & GGAGTGCGTCTACTACTGCC & GCAAACGTTAAACCTTCTTCTGTC \\
ETRA & ACTAGACGGCCTCCGGTATC & TCGGGCCATTCCTCATACAC \\
ETRB & GTGTCATGCCTGGTGTTCGT & GCCAGTCCTCTGCAAGTAGC \\
VEGFR2 & TTGGCTGGCGGTATTCACAT & GTCTCTGGAGGAAAGCACCC \\
GAPDH & GTCAACGGATTTGGCCGTAT & AATGCCAAAGTTGTCATGGATG \\
\hline
\end{tabular}


of all the experimental data generated was performed using a SPSS 13.0 statistical package program for Windows. The data were presented as mean \pm SE. Statistical significance were determined using oneway analysis of variance (ANOVA). ${ }^{*} \mathrm{p}<0.05,{ }^{* *} \mathrm{p}<0.01$ and $^{* * *} \mathrm{p}<0.001$ indicate significant difference between control and experimental groups.

\section{Results}

Endothelin (ET) signaling is involved in the chicken CAM development

We detected the mRNA expression of all ligands of the ET system in the developing chicken embryos (Fig. 1A) at embryonic 5-day (E5.0), 7-day (E7.0) and 9-day (E9.0). However, the expression level varied at different developmental stages (ET1/E5.0, E7.0, E9.0: 15.10, 14.98, 14.88; ET2/ E5.0, E7.0, E9.0: 10.16, 10.18, 10.46; ET3/ E5.0, E7.0, E9.0: 15.28, 15.12, 15.00; ET receptor A (ETRA)/ E5.0, E7.0, E9.0: 5.19, 5.5, 5.26; ET receptor B (ETRB)/ E5.0, E7.0, E9.0: 6.6, $6.29,6.38$; Fig. 1B), which was revealed using quantitative PCR. We further compared the

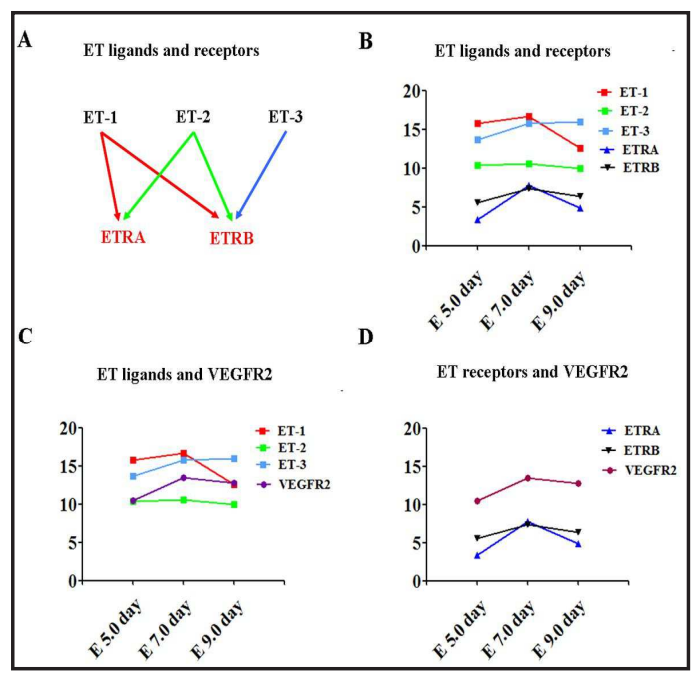

Fig. 1. Assessing the expression patterns of ET ligands and receptors in chicken CAMs. A: The sketches illustrate the variety of ET and its receptors. B-D: Quantitative PCR data showing gene expressions of ET ligands and receptors (B), ET ligands and VEGFR2 (C), ET receptors and VEGFR2 (D) at mRNA level in E5.0, E7.0, E9.0 chicken CAMs. Gene expression is shown as relative expression in relationship to the expression of GAPDH. expression of the components of the ET system with the predominant gene involved in angiogenesis, VEGF receptor 2 (VEGFR2/ E5.0, E7.0, E9.0: 12.42, 12.06, 12.25). This analysis showed that ETRB, ET-2 and ET-3 gene expression showed similar time-dependent expression patterns as compared to VEGFR2 in chicken CAMs.

Blocking ET signaling does not significantly affect non-stimulated baseline angiogenesis in chicken CAMs

Using different dosages of a combination of both ETRA and ETRB antagonists (BQ123 and BQ788), we investigated whether or not blocking ET signaling could affect baseline angiogenesis (Fig. 2A). A combination of 1,5 or $10 \mu \mathrm{g} / \mathrm{ml} \mathrm{BQ123}$ and BQ788 did not affect the BVD of chicken CAMs (Figs. 2B-E; Control $=13.57 \pm 0.91 \%, \mathrm{~N}=4 ; \mathrm{BQ} 123+\mathrm{BQ788}(1$ $\mu \mathrm{g} / \mathrm{ml})=14.06 \pm 0.61 \%, \mathrm{~N}=4 ; \mathrm{BQ} 123+\mathrm{BQ788}(5 \mu \mathrm{g} / \mathrm{ml})=15.95 \pm 0.36 \%, \mathrm{~N}=4 ; \mathrm{BQ} 123$ + BQ788 $(10 \mu \mathrm{g} / \mathrm{ml})=14.19 \pm 1.34 \%, \mathrm{~N}=4$; Fig. $2 \mathrm{~F})$. We further detected the expression of ETRA, ETRB and VEGFR2 mRNA levels in the presence of BQ123 and BQ788 exposed to chicken CAM using quantitive PCR (Figs. 2G-I). The results showed that BQ123 and BQ788 could significantly inhibit the ETRA and ETRB gene expression on chicken CAMs (Control = $1.00 \pm 0.11, \mathrm{~N}=3 ; \mathrm{BQ} 123+\mathrm{BQ788}(1 \mu \mathrm{g} / \mathrm{ml})=0.62 \pm 0.08, \mathrm{~N}=3 ; \mathrm{BQ} 123+\mathrm{BQ788}(5 \mu \mathrm{g} /$ $\mathrm{ml})=0.20 \pm 0.03, \mathrm{~N}=3 ; \mathrm{BQ} 123+\mathrm{BQ788}(10 \mu \mathrm{g} / \mathrm{ml})=0.22 \pm 0.02, \mathrm{~N}=3$; Fig. 2G; Control = $1.00 \pm 0.10, \mathrm{~N}=3 ; \mathrm{BQ} 123+\mathrm{BQ788}(1 \mu \mathrm{g} / \mathrm{ml})=0.14 \pm 0.03, \mathrm{~N}=3 ; \mathrm{BQ} 123+\mathrm{BQ788}(5 \mu \mathrm{g} /$ $\mathrm{ml})=0.33 \pm 0.04, \mathrm{~N}=3$; BQ123 + BQ788 $(10 \mu \mathrm{g} / \mathrm{ml})=0.27 \pm 0.02, \mathrm{~N}=3 ;$ Fig. $2 \mathrm{H})$. However, the VEGFR2 gene expression did not change significantly (Control $=1.000 \pm 0.02082, \mathrm{~N}=3$; $\mathrm{BQ123}+\mathrm{BQ788}(1 \mu \mathrm{g} / \mathrm{ml})=0.8067 \pm 0.08686, \mathrm{~N}=3 ; \mathrm{BQ} 123+\mathrm{BQ788}(5 \mu \mathrm{g} / \mathrm{ml})=1.169 \pm$ $0.09599, \mathrm{~N}=3 ; \mathrm{BQ123}+\mathrm{BQ788}(10 \mu \mathrm{g} / \mathrm{ml})=1.453 \pm 0.01863, \mathrm{~N}=3$; Fig. $2 \mathrm{I})$. 


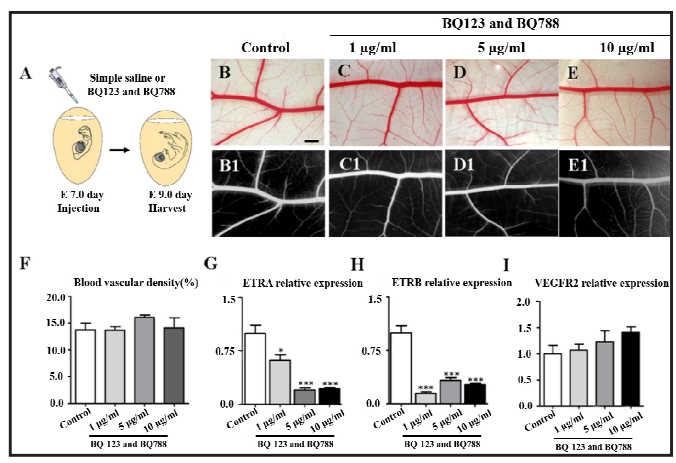

Fig. 2. The assessment of angiogenesis in chick CAM following blockage of ET receptors with antagonists. A: The sketches illustrate treatment of embryos with saline (Control) and BQ123 and BQ788. B-E1: The representative brightfield image of angiogenesis in chicken CAMs exposed to saline (Control, B), $1 \mu \mathrm{g} / \mathrm{ml}$ (C), $5 \mu \mathrm{g} /$ $\mathrm{ml}(\mathrm{D}), 10 \mu \mathrm{g} / \mathrm{ml}$ (E) of a combination of BQ123 + BQ788, respectively. B1-E1 are representative grayscale pictures. F: The bar graphs showing the comparison of BVD (\%) in chicken CAMs between Control and various concentrations of BQ123 + BQ788 groups. G-I: The quantitative PCR data show mRNA expressions of ETRA (G), ETRB (H) and VEGFR2 (I) in Control and various concentrations of BQ123 + BQ788 groups. ${ }^{*} \mathrm{p}<0.05$ and $* * * \mathrm{p}<0.001$ indicate significant difference between Control and experimental groups. Scale bars $=1 \mathrm{~mm}$ in B-E and in B-E1. ETRA, ETRB and VEGFR2 gene expression is shown as relative expression in relationship to the expression of GAPDH.

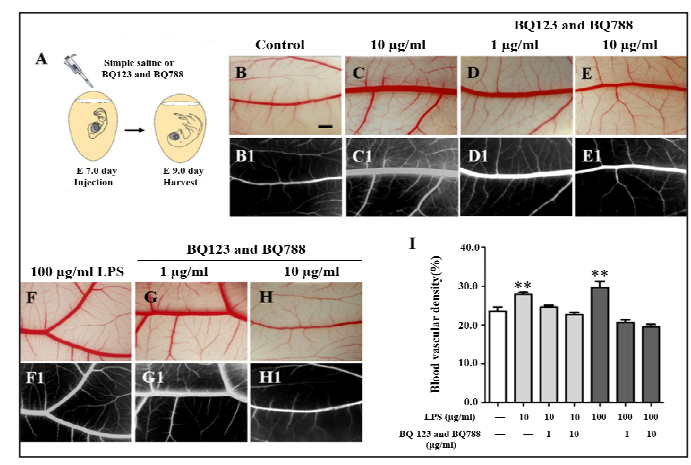

Fig. 3. The assessment of angiogenesis in chicken CAMs in absence/presence of LPS following blockage of ET receptors with antagonists. A: The sketches illustrate results of treating embryos with saline (Control) and/or LPS and/or BQ123+BQ788. B-H1: The representative bright-field images of angiogenesis on chicken CAMs exposed to simple saline (Control, B) and various concentrations of LPS or/and BQ123 + BQ788. B1-H1 are the representative grayscale pictures. I: The bar graphs showing the comparison of BVD (\%) of chicken CAMs between Control and various concentrations of LPS or/and BQ123 + BQ788 groups. ${ }^{* *} \mathrm{p}<0.01$ and ${ }^{* * *} \mathrm{p}<0.001$ indicate significant difference between Control and experimental groups. Scale bars $=1 \mathrm{~mm}$ in $\mathrm{B}-\mathrm{F}$ and in $\mathrm{H}-\mathrm{M}$.

\section{ET signaling is involved in LPS-stimulated angiogenesis on chicken CAMS}

We further investigated whether or not blocking ET signaling with BQ123 and BQ788 could affect LPS-induced angiogenesis in chicken CAMs. LPS increased in a dose dependent manner angiogenesis in chick CAM (Figs. 3A-C, F; Control $=23.43 \pm 1.14 \%, \mathrm{~N}=5$; LPS $(10$ $\mu \mathrm{g} / \mathrm{ml})=27.86 \pm 0.53 \%, \mathrm{~N}=5 ; \mathrm{LPS}(10 \mu \mathrm{g} / \mathrm{ml})+(\mathrm{BQ} 123+\mathrm{BQ788} 1 \mu \mathrm{g} / \mathrm{ml})=24.55 \pm 0.50 \%$, $\mathrm{N}=5 ; \mathrm{LPS}(10 \mu \mathrm{g} / \mathrm{ml})+(\mathrm{BQ} 123+\mathrm{BQ788} 10 \mu \mathrm{g} / \mathrm{ml})=22.63 \pm 0.56 \%, \mathrm{~N}=5 ; \mathrm{LPS}(100 \mu \mathrm{g} /$ $\mathrm{ml})+(\mathrm{BQ} 123+\mathrm{BQ788} 1 \mu \mathrm{g} / \mathrm{ml})=20.60 \pm 0.69 \%, \mathrm{~N}=5 ; \mathrm{LPS}(100 \mu \mathrm{g} / \mathrm{ml})+(\mathrm{BQ} 123+\mathrm{BQ788}$ $10 \mu \mathrm{g} / \mathrm{ml})=19.43 \pm 0.72 \%, \mathrm{~N}=5$; Fig3. I). Blocking ET signaling with two dosages of a combination of BQ123 and BQ788 normalized LPS-induced angiogenesis to baseline levels (Figs. 3B-I).

We also analyzed mRNA expressions of ETRA, ETRB and VEGFR2 in presence of LPS and/or BQ123 and BQ788 (Fig. 4). The results showed that 10 or $100 \mu \mathrm{g} / \mathrm{ml}$ LPS enhanced the expressions of ETRA, ETRB and VEGFR2 in a dose dependent manner (Control $=1.00 \pm$ $0.09, \mathrm{~N}=3 ; \mathrm{LPS}(10 \mu \mathrm{g} / \mathrm{ml})=2.53 \pm 0.19, \mathrm{~N}=3 ; \mathrm{LPS}(10 \mu \mathrm{g} / \mathrm{ml})+(\mathrm{BQ} 123+\mathrm{BQ788} 1 \mu \mathrm{g} / \mathrm{ml})$ $=1.68 \pm 0.04, \mathrm{~N}=3 ; \mathrm{LPS}(10 \mu \mathrm{g} / \mathrm{ml})+(\mathrm{BQ} 123+\mathrm{BQ788} 10 \mu \mathrm{g} / \mathrm{ml})=0.76 \pm 0.01, \mathrm{~N}=3 ; \mathrm{LPS}$ $(100 \mu \mathrm{g} / \mathrm{ml})=3.98 \pm 0.05, \mathrm{~N}=3 ; \mathrm{LPS}(100 \mu \mathrm{g} / \mathrm{ml})+(\mathrm{BQ} 123+\mathrm{BQ788} 1 \mu \mathrm{g} / \mathrm{ml})=1.70 \pm 0.08$, $\mathrm{N}=3 ; \mathrm{LPS}(100 \mu \mathrm{g} / \mathrm{ml})+(\mathrm{BQ} 123+\mathrm{BQ788} 10 \mu \mathrm{g} / \mathrm{ml})=1.70 \pm 0.08, \mathrm{~N}=3 ;$ Fig. 4A; Control = $1.00 \pm 0.02, \mathrm{~N}=3 ;$ LPS $(10 \mu \mathrm{g} / \mathrm{ml})=2.41 \pm 0.12, \mathrm{~N}=3 ;$ LPS $(10 \mu \mathrm{g} / \mathrm{ml})+(\mathrm{BQ} 123+\mathrm{BQ} 7881$ $\mu \mathrm{g} / \mathrm{ml})=2.41 \pm 0.12, \mathrm{~N}=3 ; \mathrm{LPS}(10 \mu \mathrm{g} / \mathrm{ml})+(\mathrm{BQ} 123+\mathrm{BQ788} 10 \mu \mathrm{g} / \mathrm{ml})=0.62 \pm 0.09, \mathrm{~N}=$ 3; $\mathrm{LPS}(100 \mu \mathrm{g} / \mathrm{ml})=4.98 \pm 0.18, \mathrm{~N}=3 ; \mathrm{LPS}(100 \mu \mathrm{g} / \mathrm{ml})+(\mathrm{BQ} 123+\mathrm{BQ788} 1 \mu \mathrm{g} / \mathrm{ml})=1.83$ 


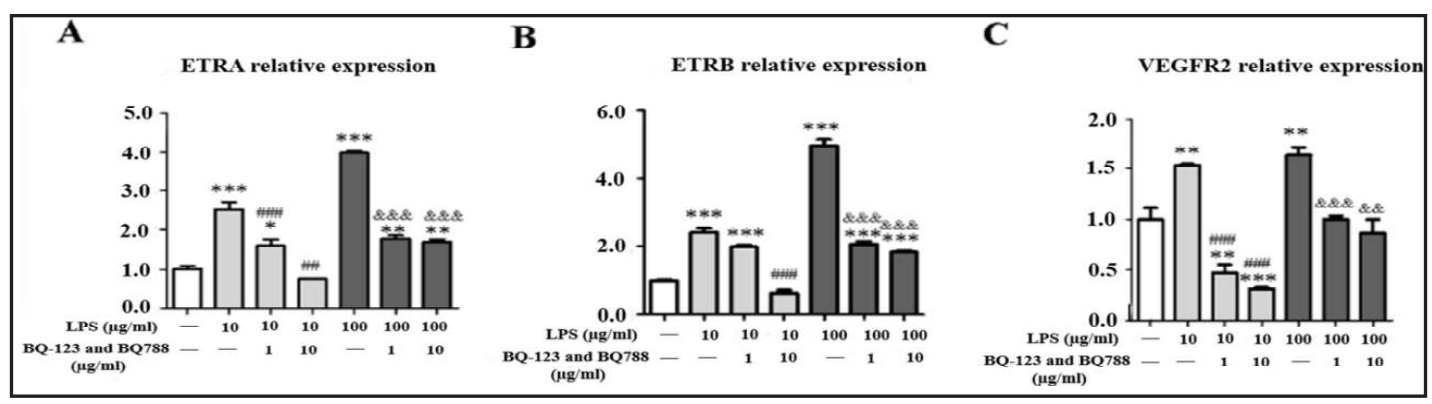

Fig. 4. Analysis of ETRA, ETRB and VEGFR2 mRNA in chicken CAMs in absence/presence of LPS following blockage of both ET receptor subtypes. A-C: The quantitative PCR data show the gene expressions of the ETRA (A), ETRB (B) and VEGFR2 (C) in each group. ${ }^{* *} \mathrm{p}<0.01$ and ${ }^{* * *} \mathrm{p}<0.001$ indicate significant difference between Control and experimental groups; ${ }^{\# \#} \mathrm{p}<0.01$ and ${ }^{\# \# \#} \mathrm{p}<0.001$ indicate significant difference between $10 \mu \mathrm{g} / \mathrm{ml} \mathrm{LPS} \mathrm{and} 10 \mu \mathrm{g} / \mathrm{ml} \mathrm{LPS} \mathrm{+} \mathrm{BQ123} \mathrm{+} \mathrm{BQ788} \mathrm{treatment} \mathrm{groups;}{ }^{\& \&} \mathrm{p}<0.01$ and \&\&\& $\mathrm{p}<0.001$ indicate significant difference between $100 \mu \mathrm{g} / \mathrm{ml}$ LPS and $100 \mu \mathrm{g} / \mathrm{ml}$ LPS + BQ123 + BQ788 treatment groups. ETRA, ETRB and VEGFR2 gene expression is shown as relative expression in relationship to the expression of GAPDH.

$\pm 0.04, \mathrm{~N}=3 ; \quad$ LPS $(100 \mu \mathrm{g} / \mathrm{ml})+(\mathrm{BQ} 123+\mathrm{BQ788} 10 \mu \mathrm{g} / \mathrm{ml})=2.07 \pm 0.08, \mathrm{~N}=3 ;$ Fig. 4B; Control $=1.00 \pm 0.12, \mathrm{~N}=3 ;$ LPS $(10 \mu \mathrm{g} / \mathrm{ml})=1.54 \pm 0.01, \mathrm{~N}=3 ; \mathrm{LPS}(10 \mu \mathrm{g} / \mathrm{ml})+(\mathrm{BQ} 123+$ $\mathrm{BQ788} 1 \mu \mathrm{g} / \mathrm{ml})=0.47 \pm 0.08, \mathrm{~N}=3 ; \mathrm{LPS}(10 \mu \mathrm{g} / \mathrm{ml})+(\mathrm{BQ} 123+\mathrm{BQ788} 10 \mu \mathrm{g} / \mathrm{ml})=0.31 \pm$ $0.02, \mathrm{~N}=3$; LPS $(100 \mu \mathrm{g} / \mathrm{ml})=1.64 \pm 0.08, \mathrm{~N}=3$; LPS $(100 \mu \mathrm{g} / \mathrm{ml})+(\mathrm{BQ} 123+\mathrm{BQ788} 1 \mu \mathrm{g} /$ $\mathrm{ml})=1.00 \pm 0.04, \mathrm{~N}=3 ;$ LPS $(100 \mu \mathrm{g} / \mathrm{ml})+(\mathrm{BQ} 123+\mathrm{BQ788} 10 \mu \mathrm{g} / \mathrm{ml})=0.86 \pm 0.14, \mathrm{~N}=3$; Fig.4C). Interestingly, both $1 \mu \mathrm{g} / \mathrm{ml}$ and $10 \mu \mathrm{g} / \mathrm{ml}$ of BQ123 and BQ788 administration could significantly suppress the LPS-induced expressions of ETRA and ETRB (Figs. 4A-C).

\section{Discussion}

The current study demonstrated that all components of the ET system are detectable during chicken embryonic development. The signal for ET-1 mRNA was most prominent and the signal for ETRA was relatively low as compared to the expression of VEGFR2, a maker of angiogenesis [12-14]. Combined blockage of ET receptors using classical ETRA and ETRB blockers did not affect baseline angiogenesis and the mRNA expression of the angiogenesis marker VEGFR2, whereas ETRA and ETRB mRNA expression were significantly decreased after combined ETRA/ETRB blockade. LPS increased angiogenesis substantially. The elevation of LPS-induced angiogenesis could be completely blocked by the treatment with a combination of the ETRA blocker - BQ123 and ETRB blocker - BQ788. This effect was accompanied by decreased expression of ETRA, ETRB, and VEGFR2. Our study did not prove that this decrease in the VEGFR2 gene expression was caused by a decreased ETRA and ETRB mRNA expression. VEGFR2 expression works simply as a marker of angiogenesis. This interpretation is consistent with all data obtained in our study. Alteration of VEGFR2 gene expression parallels to angiogenesis, which was known from previous studies. The underlying molecular pathways, which could explain the effects of combined ET receptor blockade on LPS-induced angiogenesis in contrast to no effects of combined ET receptor blockade on baseline angiogenesis in chicken embryos, remain to be elucidated.

The effect of ET-1 on angiogenesis in CAM has been well established [15-20]. However, to the best of our knowledge so far, there is no study showing that the LPS-induced angiogenesis in CAM can be blocked by the combined application of the ETA blocker BQ123 and the ETB blocker BQ 788.

In any case, it is of note that the combined blockade of the ET receptors causes a downregulation of the ETRA and ETRB mRNA expression under baseline and LPS stimulation. This is remarkable, since a pharmacological blockade of receptors usually 
causes a compensatory upregulation of the receptor mRNA and protein [21]. Again, the underlying molecular pathways explaining this unusual observation needs to be addressed in further studies.

It is a clear limitation of the current study, that only a combination of BQ123 and BQ788 was investigated. It is thus not possible to separate potential ETA specific effects from ETB meadiated effects on baseline and LPS-stimulated angiogenesis.

\section{Acknowledgements}

This study was supported by NSFC grants (81741016, 81741045, 31771331), the Science and Technology Planning Project of Guangdong Province (2017A020214015, 2017A050506029), Guangdong Natural Science Foundation (2016A030311044, 2015A030313316), the Science and Technology Program of Guangzhou (201710010054), the Fundamental Research Funds for the Central Universities (21617466, 21617463).

\section{Disclosure Statement}

The authors have declared that no competing interests exist.

\section{References}

1 Davenport AP, Hyndman KA, Dhaun N, Southan C, Kohan DE, Pollock JS, Pollock DM, Webb DJ, Maguire JJ: Endothelin. Pharmacol Rev 2016;68:357-418.

-2 Hocher B, Thone-Reineke C, Rohmeiss P, Schmager F, Slowinski T, Burst V, Siegmund F, Quertermous T, Bauer C, Neumayer HH, Schleuning WD, Theuring F: Endothelin-1 transgenic mice develop glomerulosclerosis, interstitial fibrosis, and renal cysts but not hypertension. J Clin Invest 1997;99:1380-9.

-3 Shindo T, Kurihara H, Maemura K, Kurihara Y, Ueda O, Suzuki H, Kuwaki T, Ju KH, Wang Y, Ebihara A, Nishimatsu H, Moriyama N, Fukuda M, Akimoto Y, Hirano H, Morita H, Kumada M, Yazaki Y, Nagai R, Kimura $\mathrm{K}$ : Renal damage and salt-dependent hypertension in aged transgenic mice overexpressing endothelin-1. J Mol Med (Berl) 2002;80:105-116.

4 Tsuprykov O, Chaykovska L, Kretschmer A, Stasch JP, Pfab T, Krause-Relle K, Reichetzeder C, Kalk P, Adamski J, Hocher B: Endothelin-1 Overexpression Improves Renal Function in eNOS Knockout Mice. Cell Physiol Biochem 2015;37:1474-1490.

5 Vignon-Zellweger N, Relle K, Kienlen E, Alter M, Seider P, Sharkovska J, Heiden S, Kalk P, Schwab K, Albrecht-Kupper B, Theuring F, Stasch JP, Hocher B: Endothelin-1 overexpression restores diastolic function in eNOS knockout mice. J Hypertens 2011;29:961-970.

6 Xu M, Lu YP, Hasan AA, Hocher B: Plasma ET-1 Concentrations are Elevated in Patients with Hypertension Meta-Analysis of Clinical Studies. Kidney Blood Press Res 2017;42:304-313.

-7 Lu YP, Hasan AA, Zeng S, Hocher B: Plasma ET-1 Concentrations Are Elevated in Pregnant Women with Hypertension -Meta-Analysis of Clinical Studies. Kidney Blood Press Res 2017;42:654-663.

$>8$ He YQ, Li Y, Wang XY, He XD, Jun L, Chuai M, Lee KK, Wang J, Wang LJ, Yang X: Dimethyl phenyl piperazine iodide (DMPP) induces glioma regression by inhibiting angiogenesis. Exp Cell Res 2014;320:354-364.

-9 Wang G, Zhong S, Zhang SY, Ma ZL, Chen JL, Lu WH, Cheng X, Chuai M, Lee KK, Lu DX, Yang X: Angiogenesis is repressed by ethanol exposure during chick embryonic development. J Appl Toxicol 2016;36:692-701.

10 Wang G, Chen BZ, Wang CJ, Zhang J, Gao LR, Chuai M, Bao Y, Yang X: Ethanol exposure leads to disorder of blood island formation in early chick embryo. Reprod Toxicol 2017;73:96-104.

11 Ma ZL, Wang G, Lu WH, Cheng X, Chuai M, Lee KK, Yang X: Investigating the effect of excess caffeine exposure on placental angiogenesis using chicken 'functional' placental blood vessel network. J Appl Toxicol 2016;36:285-295. 


\section{Cellular Physiology Cell Physiol Biochem 2018;48:2084-2090

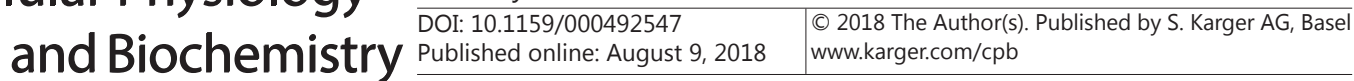 \\ Wang et al.: ET Signaling Is Vital for LPS Induced Angiogenesis}

12 Pyriochou A, Tsigkos S, Vassilakopoulos T, Cottin T, Zhou Z, Gourzoulidou E, Roussos C, Waldmann $\mathrm{H}$, Giannis A, Papapetropoulos A: Anti-angiogenic properties of a sulindac analogue. Br J Pharmacol 2007;152:1207-1214.

13 Chiang KC, Sun CC, Chen MH, Huang CY, Hsu JT, Yeh TS, Chen LW, Kuo SF, Juang HH, Takano M, Kittaka A, Chen TC, Yeh CN, Pang JH: MART-10, the new brand of 1alpha,25(OH)2D3 analog, is a potent antiangiogenic agent in vivo and in vitro. J Steroid Biochem Mol Biol 2016;155:26-34.

14 Takahashi T, Takase Y, Yoshino T, Saito D, Tadokoro R, Takahashi Y: Angiogenesis in the developing spinal cord: blood vessel exclusion from neural progenitor region is mediated by VEGF and its antagonists. PLoS One 2015;10:e0116119.

15 Bagnato A, Spinella F: Emerging role of endothelin-1 in tumor angiogenesis. Trends Endocrinol Metab 2003;14:44-50.

16 Cruz A, Parnot C, Ribatti D, Corvol P, Gasc JM: Endothelin-1, a regulator of angiogenesis in the chick chorioallantoic membrane. J Vasc Res 2001;38:536-545.

17 Fanton Y, Houbrechts C, Willems L, Daniels A, Linsen L, Ratajczak J, Bronckaers A, Lambrichts I, Declercq J, Rummens JL, Hendrikx M, Hensen K: Cardiac atrial appendage stem cells promote angiogenesis in vitro and in vivo. J Mol Cell Cardiol 2016;97:235-244.

18 Lu J, Zhao FP, Peng ZL, Zhang MW, Lin SX, Liang BJ, Zhang B, Liu X, Wang L, Li G, Tian WD, Peng Y, He ML, Li XP: EZH2 promotes angiogenesis through inhibition of miR-1/Endothelin-1 axis in nasopharyngeal carcinoma. Oncotarget 2014;5:11319-11332.

19 Ribatti D, Presta M, Vacca A, Ria R, Giuliani R, Dell'Era P, Nico B, Roncali L, Dammacco F: Human erythropoietin induces a pro-angiogenic phenotype in cultured endothelial cells and stimulates neovascularization in vivo. Blood 1999;93:2627-2636.

20 Wu MH, Huang CY, Lin JA, Wang SW, Peng CY, Cheng HC, Tang CH: Endothelin-1 promotes vascular endothelial growth factor-dependent angiogenesis in human chondrosarcoma cells. Oncogene 2014;33:1725-1735.

-21 Hocher B, Merker HJ, Durr JA, Schiller S, Gross P, Hensen J: Internalization of V2-vasopressin receptors in LLC-PK1-cells: evidence for receptor-mediated endocytosis. Biochem Biophys Res Commun 1992;186:1376-1383. 